\author{
Sonja N. Pajić* \\ Fakultet društvenih nauka, Beograd \\ Danijela D. Đorđević** \\ Univerzitet u Beogradu, Poljoprivredni fakultet, Beograd-Zemun \\ Kristina V. Marković ${ }^{* * *}$ \\ Univerzitet u Beogradu, Poljoprivredni fakultet, Beograd-Zemun
}

\title{
AUDIO-VIZUELNA SREDSTVA U NASTAVI STRANIH JEZIKA STRUKE
}

\author{
Originalni naučni rad \\ UDC 371.3::81'243 \\ https://doi.org/10.18485/kkonline.2020.11.11.9
}

\begin{abstract}
U cilju osavremenjivanja nastave stranih jezika struke i povećanja motivacije studenata, neprestano se teži poboljšanju kako nastavnih materijala, tako i uvođenju različitih sredstava u nastavni proces. Shodno tome, u radu se razmatraju prednosti primene audio-vizuelnih sredstava u didaktičke svrhe. Za potrebe istraživanja sprovedena je anketa među predavačima stranog jezika struke na Univerzitetu u Beogradu, kao i među studentima druge godine osnovnih studija koji su pohađali nastavu stranog jezika struke na Poljoprivrednom fakultetu Univerziteta u Beogradu. Predmet istraživanja rada podrazumeva ispitivanje stava predavača i studenata stranog jezika struke prema primeni audio-vizuelnih sredstava u nastavi. Cilj istraživanja sastoji se u sagledavanju (ne)postojanja preduslova za primenu audio-vizuelnih sredstava u nastavi stranih jezika struke. Rezultati istraživanja ukazuju na brojne prednosti primene audio-vizuelnih sredstava u nastavi stranog jezika struke i potrebu za njihovim korišćenjem i neophodnosti daljih istraživanja u ovoj oblasti. Kako predavači tako i studenti smatraju da je upotreba audiovizuelnih sredstava u nastavi veoma korisna jer pre svega čini nastavu zanimljivijom a gradivo jasnijim, te na taj način motiviše studente za učenje stranog jezika struke.
\end{abstract}

Ključne reči: strani jezik struke, audio-vizuelna sredstva, jezičke veštine i kompetencije, istraživanje, stavovi predavača/studenata

\section{Uvod}

Audio-vizuelna sredstva svakodnevno su prisutna i dostupna u savremenom društvu. Tako su i studenti u velikoj meri izloženi različitim audio i video sredstvima koji su im lako dostupni preko interneta i različitih platformi i aplikacija. Mnogi autori su mišljenja da bi ova sredstva trebalo iskoristiti u obrazovnom procesu jer proizilaze iz novih struktura društva i kulture, te na taj način obezbeđuju različite pristupe znanjima i tumačenjima stvarnosti (Sarceda Gorgoso \& Raposo Rivas 2009: 39). S

\footnotetext{
* Bulevar umetnosti 2a, Beograd, sonjahornjak@live.com.

**Nemanjina 6, Beograd - Zemun, ddj@agrif.bg.ac.rs.

*** Nemanjina 6, Beograd - Zemun, markovic.kristina@gmail.com.
} 
obzirom na to da se didaktička sredstva konstantno unapređuju, potrebno je neprestano pratiti savremene tendencije $u$ tehnologiji koje mogu doprineti usavršavanju i poboljšanju nastavnog procesa.

Kopen (Coppen 1978: 201) smatra da je obrazovnom sistemu potrebno nešto više od profesora i knjiga, kao i da on treba da prati audio-vizuelnu kulturu i koristi sve kanale koji prenose vizuelne i verbalne poruke. Stoga upotreba različitih audiovizuelnih zapisa može poboljšati nastavu stranih jezika struke donekle približavajući određene sadržaje studentima. Na taj način studenti će možda lakše usvojiti nove leksičke jedinice i gramatičke strukture. Audio-vizuelna sredstva odlikuju se brojnim karakteristikama koje pružaju prednosti u didaktičkom smislu, kao što su autentičnost, jezički input, simultano primenjivanje čula vida i sluha. Uvođenje ovih sredstava u nastavu stranog jezika struke može takođe povećati motivaciju studenata i stvoriti prijatnu atmosferu za rad.

Predmet istraživanja datoga rada obuhvata ispitivanje stavova predavača i studenata stranog jezika struke prema primeni audio-vizuelnih sredstava u nastavi. Cilj istraživanja podrazumeva sagledavanje (ne)postojanja preduslova za primenu ovih sredstava u nastavi stranih jezika struke. Pojedini radovi koji se bave primenom audiovizuelnih sredstava u nastavi engleskog kao jezika struke postoje kod nas (Milošević 2017), ali iscrpnija istraživanja o stavu profesora prema njihovoj primeni nisu do sada rađena.

U daljem izlaganju biće dat prikaz pre svega prednosti upotrebe audio-vizuelnih sredstava u nastavi, zatim će biti opisana metodologija istraživanja i u završnom delu rada rezultati, ograničenja istraživanja, kao i implikacije za primenu u nastavi i za buduća istraživanja u ovoj oblasti.

\section{Teorijski okvir}

\subsection{Prednosti audio-vizuelnih sredstava u nastavi stranog jezika struke}

U svakodnevnoj komunikaciji osobe većinu informaija dobijaju istovremeno putem čula vida i sluha. Slično je i sa upotrebom audio-vizuelnih sredstava, u kojima spoj vizuelnih i zvučnih elemenata pruža kompletno značenje poruke (Ferrés Prats 1992: 96). Još 1992. godine Feres Prats (Ferrés Prats 1992: 38-39) sproveo je istraživanje kojim je pokazano da su učenici u nastavi koja se zasniva na usmenom prenošenju usvojili nakon tri sata $70 \%$ informacija, a nakon tri dana samo $10 \%$ informacija. Vizuelnim putem zapamtili su $72 \%$ nakon tri sata, a $20 \%$ informacija nakon tri dana, dok su posle kombinovane metode upamtili $85 \%$ nakon tri sata i $65 \%$ 
informacija nakon tri dana (Ferrés Prats 1992: 38-39). Prednosti audio-vizuelnog formata su prikazivanje konkretnih značenja (Ferrés Prats 2000: 25), kao i kontekstualizovanih slika (Canning-Wilson \& Wallace 2000: 2), koje u nastavi stranih jezika pružaju izvor realnog jezičkog inputa (Allan 1985: 49). Audio-vizuelna sredstva takođe prikazuju i ekstralingvističke elemente (Canning-Wilson \& Wallace 2000: 3). Kombinacija verbalne, paraverbalne i neverbalne komunikacije veoma je značajna za usvajanje stranih jezika (Biedma Torrecillas \& Torres Sánchez 1994: 538; Brandimonte 2003: 871). Pored toga, u radu sa audio-vizuelnim sredstvima postoji mogućnost da se učenik približi udaljenim stvarnostima (Molina i Simó 1990: 24). Milošević (2017: 19) takođe tvrdi da audio-vizuelni sadržaji mogu da predstavljaju konkretne primere preko jezičkih i vanjezičkih elemenata koje sadrže, pri čemu apstraktne ideje praćene konkretnim vizuelnim prezentacijama mogu da budu razumljivije publici.

Upotrebom audio-vizuelnih sredstava i odgovarajućih propratnih aktivnosti mogu se unaprediti sve komponente lingvističke kompetencije (leksička, gramatička, semantička, fonološka i pravopisna). Leksička i gramatička kompetencija se razvijaju kroz rad putem dijaloga, odnosno izgovorenim rečenicama u audio-vizuelnom sadržaju, dok se fonološka kompetencija usavršava kroz slušanje zvučnog inputa, uočavanjem fonema, fonetskih struktura reči i prozodijskih elemenata. Semantička kompetencija razvija se putem direktnog posmatranja značenja, dok se pravopisna kompetencija razvija izradom propratnih aktivnosti koje se zasnivaju na pogledanom audio-vizuelnom sadržaju (Hornjak 2017: 19)

Rad sa audio-vizuelnim sredstvima utiče i na kognitivne procese. Kombinacija ludičkih elemenata u audio-vizuelnom formatu utiče na motivaciju učenika (Allan 1985: 49), a od izuzetnog značaja je i činjenica da su ova sredstva pokretač za usmeno izražavanje (Ferrés Prats 1992: 38-39). Audio-vizuelna sredstva predstavljaju deo aktivnog oblika nastave uključujući učestvovanje učenika kao i zadatke koji se učenicima zadaju (Brady 1992: 172). Istraživanje koje su sproveli Kening-Vilson i Volis (Canning-Wilson \& Wallace 2000: 2) potvrdilo je da učenici stranog jezika umnogome imaju pozitivan stav prema audio-vizuelnim sredstvima u nastavi.

Pored lingvističkih sadržaja koje pruža jezički input, u nastavi stranih jezika struke audio-vizuelna sredstva prikazuju i sociokulturne sadržaje. Međutim, pored prikazanog sadržaja potrebno je takođe pripremiti propratne aktivnosti za razvijanje ciljeva koji se žele postići, tako da se mogu razvijati sve četiri osnovne jezičke veštine.

Smatra se da su strani jezici struke interdisciplinarni i u velikoj meri povezani sa različitim akademskim disciplinama, unutar i izvan lingvistike, npr. sa pragmatikom, 
analizom diskursa, sociolingvistikom, kognitivnom lingvistikom, leksikografijom, jezičkim planiranjem, semantikom i mnogim drugim disciplinama (Gollin-Kies et al. 2015: 17). Imajući dakle u vidu složenost i specifičnosti nastave stranih jezika struke, različite vrste sredstava mogu se primeniti u nastavi kako bi se studenti što više motivisali i nastava učinila zanimljivijom i privlačnijom. Do sada je sproveden značajan broj istraživanja u kojima se ispitivalo da li i u kojoj meri upotreba audio-vizuelnih sredstava može da utiče na učenje i razvijanje određenih veština kod studenata. Pokazalo se da je upotreba video zapisa pozitivno uticala na razvijanje sposobnosti razumevanja odslušanog zapisa, kao i da su studenti imali pozitivan stav prema upotrebi video sredstava u nastavi (npr. Woottipong 2014), a takođe i da je upotreba audio-vizuelnih sredstava pozitivno uticala na postignuća studenata (Al-Khayyat 2016), kao i da postoje brojne prednosti koje studenti imaju od korišćenja audiovizuelnih sredstava (Ashaver \& Igyuve 2013). Pored toga, pokazalo se da je učenje engleskog jezika struke efikasnije uz pomoć audio-vizuelnih sredstava (Mutar 2009). Takođe, istraživanje sprovedeno u Srbiji u vezi sa upotrebom audio-vizuelnih sredstava u nastavi engleskog jezika za tehničke nauke pokazalo je da studenti audiovizuelna sredstva smatraju prijatnijim i efikasnijim u poređenju sa pisanim materijalom (Milosevic 2017). Vrste audio-vizuelnih sredstava koje se mogu primeniti u nastavi stranih jezika struke su raznolike i obuhvataju filmove, dokumentarne filmove, reportaže, televizijske serije, reklame, filmske trejlere i dr. Primena video materijala u nastavi engeskog kao jezika struke otvara nove mogućnosti ne samo za studente već i za profesore (Radosavlevikj \& Hajrullai 2019: 179).

Imajući u vidu sve navedeno sproveli smo istraživanje među predavačima stranog jezika struke na nefilološkim fakultetima Univerziteta u Beogradu i studentima Poljoprivrednog fakulteta o upotrebi audio-vizelnih sredstava u nastavi stranih jezika struke.

\section{Metodologija}

U cilju sagledavanja značaja koje audio-vizuelna sredstva imaju u nastavi jezika struke i stava predavača i studenata prema njihovoj upotrebi u nastavi sprovedena su dva istraživanja. Tehnika prikupljanja podataka za oba istraživanja bila je anketa, a instrument upitnik. Upitnik za nastavnike/predavače stranih jezika struke sastojao se od 12 pitanja otvorenog i zatvorenog tipa. Pitanja su se odnosila na vrstu audiovizuelnih sredstava koja se primenjuju u nastavi, učestalost njihove primene, postojanje tehničkih uslova za primenu i procenu njihove efikasnosti u nastavi. Upitnik 
namenjen studentima sastojao se od 10 pitanja otvorenog i zatvorenog tipa, sa ciljem da se ispita stav studenata prema upotrebi audio-vizuelnih sredstava u nastavi stranih jezika struke. Upitnik je potencijalnim ispitanicima bio poslat putem elektronske pošte.

Prvim uzorkom bili su obuhvaćeni predavači stranog jezika struke na različitim nefilološkim fakultetima Univerziteta u Beogradu (predavači engleskog, nemačkog, ruskog, francuskog, španskog i italijanskog jezika). Upitnik je poslat na ukupno trideset adresa, a dobijeno je osamnaest odgovora $(n=18)$, te se stoga ovo može smatrati i jednim od ograničenja datog istraživanja.

Drugi uzorak činili su studenti druge godine odseka Agroekonomija na Poljoprivrednom fakuletetu Univerziteta u Beogradu. Studenti su pohađali predmete Engleski jezik i Nemački jezik u toku zimskog semestra školske 2016/2017. godine. Na upitnik je dobrovoljno odgovorilo ukupno 32 studenta $(n=32)$. U toku nastave bili su korišćeni su različiti kratki filmovi na engleskom odnosno nemačkom jeziku povezani sa stručnim temama koje su obrađivane. Studenti su prvo slušali određeni audio zapis ili gledali filmski sadržaj, a zatim su im zadavane različite aktivnosti u vezi sa obrađenim temama, poput diskusija, debata i grupnih prezentacija, kao i aktivnosti (npr. upitnici, kvizovi) kako bi se proverilo razumevanje poslušanog i pogledanog materijala. Navedena sredstva korišćena su prilikom uvođenja nove teme kako bi se studentima lakše i interesantnije predstavio određeni stručni sadržaj ili posle pročitanog teksta o određenoj stručnoj oblasti kako bi im se pročitani sadržaj dodatno približio. Takođe, ova sredstva su se pokazala vrlo korisnim prilikom utvrđivanja gradiva, kao i za započinjanje diskusija u vezi sa obrađenom temom iz oblasti struke. Istraživanje smo započeli imajući u vidu dve hipoteze. Prva hipoteza je bila da predavači poseduju pozitivan stav, ali da ne koriste sistematski audio-vizuelna sredstva u nastavi stranog jezika struke. Druga hipoteza je bila da studenti pozitivno ocenjuju upotrebu audio-vizuelnih sredstava u nastavi stranog jezika struke. Ovde smo pošli od pretpostavke da korišćenje audio-vizuelnih sredstava dodatno motiviše studente. Korišćenjem ovih sredstava studentima se donekle približavaju određene teme i na taj način im se olakšava usvajanje jezika i razvijanje drugih kompetencija, npr. lingvističke, sociolingvističke, interkulturalne i pragmatske kompetencije. Ispitanici, kako predavači tako i studenti, unapred su bili obavešteni da je upitnik anoniman i da će se podaci dobijeni upitnikom koristiti isključivo u naučne svrhe. 


\section{Rezultati i diskusija}

\subsection{Stavovi predavača prema upotrebi audio-vizuelnih sredstava u nastavi stranih jezika struke}

Upitnik namenjen predavačima stranog jezika struke sadržao je pitanja otvorenog i zatvorenog tipa koja se odnose na primenu audio-vizuelnih sredstava, učestalost njihove primene, razloge za primenu, zainteresovanost studenata, vrste audio-vizuelnih sredstava koje se koriste, tehničke uslove na fakultetima, vrste aktivnosti koje se primenjuju u nastavi, prednosti i mane primene ovih sredstava, kao i postojanje ili nepostojanje potrebe za obukom predavača. Rezultati upitnika izraženi su u procentima.

Prvim pitanjem u upitniku namenjenom predavačima stranog jezika struke težili smo da utvrdimo zastupljenost primene audio-vizuelnih sredstava u nastavi stranih jezika struke. Svi ispitanici (100\%) izjavili su da koriste audio-vizuelna sredstva u nastavi. Dobijeni podatak je vrlo ohrabrujući s obzirom na to da se nije očekivalo da svi predavači koriste ova sredstva u nastavi. Ovde bi svakako bilo od važnosti napomenuti da se nisu svi predavači nefiloloških fakulteta u Beogradu odazvali ovoj anketi, te bi dobijene rezultate svakako trebalo potvrditi u nekim budućim istraživanjima.

Kada su u pitanju razlozi primene/neprimene audio-vizuelnih sredstava u nastavi stranog jezika struke, ispitanici smatraju da primenom audio-vizuelnih sredstava u nastavi stranog jezika struke studenti mogu lakše usvojiti određene termine i steći širu sliku o određenim pojmovima, kao i da se na ovaj način može uvesti ciljni vokabular. Primenom audio-vizuelnih sredstava olakšava se usvajanje gradiva, razvijaju se veštine slušanja i usmenog razumevanja jer ova vrsta nastavnih resursa pruža podsticaj za razgovor/diskusiju. S obzirom na to da ova sredstva predstavljaju uglavnom autentične materijale, studenti su u mogućnosti da čuju i govor izvornih govornika. Audio-vizuelna sredstva takođe olakšavaju nastavu u smislu što boljeg približavanja određene materije, te studentima gradivo postaje bliže i jasnije. Neki od ispitanika smatraju da su ovakva sredstva praktično neophodna u nastavi. Na ovaj način može se takođe proveriti napredak studenata, a ujedno se omogućava i raznovrsnost nastave, jer se ona unapređuje i čini interesantnijom. Ispitanici takođe smatraju da su ovakva sredstva studentima zanimljiva kao i da ih istovremeno motivišu da aktivno učestvuju u diskusiji vezanoj za temu koja se obrađuje.

Na pitanje o učestalosti upotrebe audio-vizuelnih sredstava na časovima u okviru nastave stranog jezika struke, predavači kao odgovor ističu da ih najčešće koriste 
nekoliko puta mesečno (77,8\%), a $16,7 \%$ ispitanika upotrebljava audio-vizuelna sredstva u nastavi jednom u toku meseca, dok ih veoma mali broj predavača $(5,5 \%)$ upotrebljava samo jednom u toku semestra. Po pitanju zainteresovanosti studenata za rad sa audio-vizuelnim sredstvima, svi ispitanici predavači bili su jednoglasni i izjavili su da su studenti veoma zainteresovani.

U vezi sa konkretnom vrstom audio-vizuelnih sredstava koja se koristi u nastavi stranog jezika struke u upitniku kao odgovori prednjače dokumentarni filmovi $(66,7 \%)$, na drugom mestu su filmovi $(55,6 \%)$, a zatim reportaže $(44,4 \%)$. U nastavi su najmanje zastupljeni video materijali za strance $(16,7 \%)^{1}$, inserti iz televizijskih serija $(5,6 \%)$, reklame $(5,6 \%)$ i filmski trejleri (5,6\%). Pored toga, 44,4\% ispitanika navelo je da koristi i druge audio-vizuelne formate, kao što su materijali sa interneta u vidu kratkih klipova različitih sadržaja (npr. inserti iz televizijskih i radijskih programa, klipovi sa različitih kanala i društvenih mreža).

Na pitanje u vezi sa postojanjem tehničkih uslova na fakultetima za korišćenje audio-vizuelnih sredstava u nastavi kao što su oprema i internet, svi ispitanici predavači su potvrdili da na fakultetu postoje odgovarajući uslovi. Pomenuti nalaz predstavlja bitan preduslov za moguću širu primenu audio-vizuelnih sredstava u nastavi stranog jezika struke.

S obzirom na to da su za rad sa audio-vizuelnim sredstvima neophodne propratne aktivnosti, jedno od postavljenih pitanja u upitniku glasilo je da li predavači sami smišljaju vežbanja ili koriste već postojeća. Ukupno 83,3\% ispitanika odgovorilo je da sami smišljaju vežbanja, dok $55,6 \%$ ispitanika koristi gotove aktivnosti. Na osnovu odgovora ispitanika predavača može se primetiti da pojedini predavači koriste obe vrste vežbanja.

Predavači stranog jezika struke smatraju dalje da se upotrebom audio-vizuelnih sredstava najviše razvijaju veštine razumevanja govora (100\% ispitanika) i veštine usmenog izražavanja (88,9\%). Nešto manji procenat ispitanika $(27,8 \%)$ smatra da se na taj način razvijaju veštine pismenog izražavanja i razumevanja pisanog teksta $(16,7 \%)$. Na postavljeno pitanje o tome koje se kompetencije razvijaju upotrebom audio-vizuelenih sredstava, svi ispitanici smatraju da se razvijaju lingvistička i sociokulturna kompetencija, dok je $77,8 \%^{2}$ ispitanika mišljenja da se razvija pragmatska kompetencija.

\footnotetext{
${ }^{1}$ Pod video materijalima za strance podrazumevamo ciljano osmišljene audio-vizeulne klipove čiji je cilj učenje stranog jezika i namenjeni su neizvornim govornicima.

2 Ponuđeni odgovori bili su tako koncipirani da je ispitanik mogao da izabere više odgovora, odnosno da iznese stav da se više kompetencija može razviti primenom audio-vizelnih sadržaja u nastavi.
} 
Naredno pitanje odnosilo se na prednosti primene audio-vizuelnih sredstava u nastavi stranog jezika struke. Svi ispitanici su odgovorili da prepoznaju prednosti koje u nastavi imaju ova audio-vizuelna sredstva. Ona utiču pre svega na povećanje motivacije studenata jer postoji diversifikacija nastavnog sadržaja. Studenti su motivisaniji jer im se čini da rade nešto što ima veze sa "stvarnim svetom" i što će im u budućem životu i radu biti od koristi. Časovi su zanimljiviji jer se studenti zahvaljujući autentičnosti ovih sredstava susreću sa izvornim govornicima i drugom kulturom, odnosno upoznaju se sa autentičnim jezikom i govorom. Audio-vizuelna sredstva takođe pružaju mogućnost razvijanja jezičkih, interkulturalnih i kompetencija potrebnih za ovladavanje jezikom struke. Zahvaljujući ovim sredstvima, studenti se upoznaju sa savremenim i aktuelnim jezikom, ona upućuju učenike u nijanse u upotrebi jezika na pragmatičkom i stilističkom nivou. Njihovom upotrebom nastava je mnogo efikasnija jer studenti lakše usvajaju određene termine, ali i čitave konstrukcije na ciljnom stranom jeziku. Na ovaj način podstiče se aktivnost studenata i povećava njihova motivacija. Studenti se osećaju opuštenije, motivisanije i zainteresovanije jer im je okruženje interneta, mobilnih telefona i kompjutera veoma blisko.

Na pitanje o izvesnim nedostacima upotrebe audio-vizuelnih sredstava u nastavi, određeni broj predavača ispitanika $(27,8 \%)$ mišljenja je da ovaj način rada nema nedostataka, dok su pojedini ispitanici naveli sledeće nedostatke: ukoliko studenti poseduju nizak nivo poznavanja stranog jezika, praćenje sadržaja čak i vrlo jednostavnih kratkih filmova prilično je teško, te tako to na njih deluje obeshrabrujuće i stresno. Ispitanici su dalje naveli da sama audio-vizuelna sredstva nemaju nedostatke, već su jedini problem loši tehnički uslovi za sprovođenje takvog vida nastave na fakultetu. Naime, učionice na fakultetima su uglavnom opremljene internetom i kompjuterima, ali se nastava odvija u velikim amfiteatrima, koji ne poseduju ozvučenje.

$\mathrm{Na}$ postavljeno pitanje u vezi sa stručnim usavršavanjem predavača, $83,3 \%$ ispitanika predavača smatra da bi seminari i obuke bili korisni, dok 16,7\% smatra da ne postoji potreba za obukom ove vrste. Ovaj rezultat ukazuje na to da predavači smatraju kako bi dodatnim obukama proširili znanje koje poseduju u vezi sa primenom datih resursa u nastavi stranih jezika struke. 


\subsection{Stavovi studenata prema upotrebi audio-vizuelnih sredstava u nastavi stranih jezika struke}

Kao što je već navedeno, uzorak za drugo istraživanje činili su studenti koji su pohađali nastavu u kojoj su korišćena audio-vizuelna sredstva. Cilj upitnika bio je saznati da li studentima ispitanicima korišćena sredstva bila od koristi, te da li bi želeli više ovakvih sredstava u toku nastave, da li im je gradivo zanimljivije i mogu li lakše da zapamte gradivo, kao i da li se u takvoj atmosferi osećaju prijatno i opušteno. Takođe, studenti ispitanici bili su upitani i da li su imali poteškoća u razumevanju prezentovanih materijala i na kraju trebalo je da navedu delove prezentovanih sadržaja koji su im se svideli, odnosno nisu svideli.

Na pitanje postavljeno studentima da li im se časovi na kojima se koriste audiovizuelna sredstva dopadaju, većina ispitanika odgovorila je potvrdno $(87,5 \%$ u potpunosti se slaže, a $12,5 \%$ ispitanika se delimično slaže). Ispitanici studenti naveli su sledeće razloge koji govore u prilog gorenavedenoj tvrdnji: atmosfera na času je bez stresa, zanimljiva, neobična i rasterećena; neki od ispitanika smatraju da je ovo najbolji način za razmenjivanje informacija, te su naveli i dinamičnost predavanja. Studenti ispitanici su takođe naveli kao jedan od pozitivnih razloga i veću zainteresovanost za odgovarajuću temu uz upotrebu audio-vizuelnih sredstava.

$\mathrm{Na}$ pitanje da li bi želeli da imaju više časova u koje je uključena upotreba ovakvih materijala, većina studenata je odgovorila potvrdno (69\%), 25\% ispitanika se delimično slaže, dok jedan manji broj ispitanika (6\%) nije siguran da li bi želeo više časova takvog tipa. S ovim u vezi, treba svakako imati u vidu i činjenicu da ima studenata čije poznavanje stranog jezika nije na visokom nivou, tako da tim studentima deo časa na kome se određeni sadržaj gleda i/ili sluša predstavlja poteškoću, jer je njima teško da u potpunosti razumeju sadržaj materijala koji im se prezentuje.

Kada je reč o gradivu koje se obrađuje i pitanju da li je ono na ovaj način predstavljeno zanimljivije, moglo se i očekivati da će se ispitanici najvećim delom dati potvrdan odgovor da je gradivo zanimljivije uz ovakav vid nastave ( $81 \%$ ispitanika slaže se u potpunosti, dok se $19 \%$ ispitanika slaže samo delimično). Studenti su dakle jasno istakli da im je rad na ovaj način mnogo interesantniji, te pretpostavljamo da ovakav model rada sigurno pozitivno utiče i na njihovu motivaciju za učenje stranog jezika struke.

Na pitanje da li se gradivo lakše usvaja uz primenu audio-vizuelnih sredstava u nastavi, veći procenat ispitanika odgovorio je potvrdno (75\%), određeni broj studenata 
se delimično slaže sa navedenom tvrdnjom (19\%), dok je manji procenat ispitanika $(6 \%)$ ostao neodlučan. Pored toga, gotovo svi ispitanici studenti (94\%) odgovorili su da se u potpunosti slažu sa tvrdnjom da se osećaju opušteno i prijatno prilikom korišćenja filmova na stranom jeziku u nastavi, dok se samo mali procenat ispitanika studenata (6\%) delimično slaže sa pomenutom tvrdnjom. Kao što smo već naveli, nisu svi studenti podjednakog nivoa poznavanja stranog jezika, nekima je lakše, a nekima teže da prate nastavu. Iako većini studenata prija ovakav vid nastave, sigurno je da postoji izvestan broj njih koji nisu voljni da slušaju ili gledaju strane audio odnosno video zapise. Oni se tada osećaju nelagodno i skučeno, a to sve u najvećoj meri delom proizilazi iz nedovoljnog poznavanja stranog jezika.

Veći deo studenata ispitanika mogao je bez poteškoća da razume i prati film na stranom jeziku (63\%), 31\% ispitanika je delimično moglo da prati filmove, dok 6\% ispitanika nije moglo da proceni koliko od sadržaja filma je uspelo da razume. Dakle, u obzir opet treba uzeti različit nivo znanja stranog jezika studenta, pa stoga svakako i njihovo razumevanje audio-vizuelnih sredstava.

Delovi filma koji su na studente ispitanike ostavili poseban utisak bile su sekvence u vezi sa temom o zagađenju, uništavanju prirode i životne sredine, prikaza ponude i tražnje, održivosti poljoprivrede, kao i troškova, dok je veći deo ispitanika naveo da im se sve u filmovima sviđa ili da ne mogu da izdvoje određene delove jer se ne sećaju, a samo jedan od ispitanika naveo je neadekvatno ozvučenje kao razlog nerazumevanja sadržine filmova, dok je takođe samo jedan ispitanik odgovorio da mu se uopšte filmovi u kojima se obrađuju stručne teme nisu dopali jer su monotoni.

$\mathrm{Na}$ osnovu dobijenih rezultata ankete može se zaključiti da studenti uglavnom pozitivno ocenjuju upotrebu audio-vizuelnih sredstava u nastavi stranog jezika stuke, ali da isto tako postoji i jedan određeni broj ispitanika koji nisu u potpunosti zadovoljni bilo sadržajem (teme im nisu zanimljive) bilo tehničkom opremljenošću (nedostojanje adekvatnog ozvučenja).

\section{Zaključak}

Audio-vizuelna sredstva nalaze sve širu primenu u savremenoj nastavi stranog jezika, pa tako i u nastavi stranog jezika struke na nefilološkim fakultetima. Sprovedenim istraživanjem došlo se do značajnih rezultata o tome kakvi su zaista stavovi i predavača i studenata prema upotrebi audio-vizuelnih sredstava u nastavi.

U okviru datog istraživanja pošlo se od dve hipoteze. Prva hipoteza imala je za pretpostavku da predavači imaju pozitivan stav prema upotrebi audio-vizuelnih 
sredstava u nastavi stranih jezika, ali da ih ne koriste sistemski, dok se druga hipoteza odnosila na to da studenti pozitivno ocenjuju upotrebu ovih audio-vizuelnih sredstava u nastavi.

Na osnovu rezultata datog istraživanja, može se zaključiti da predavači imaju pozitivan stav prema primeni audio-vizuelnih sredstava u nastavi stranog jezika struke. Dobijeni podaci su od velike važnosti jer je do sada primena ovih sredstava samo sporadična, te se može zaključiti da postoji dobra osnova za sistematsku primenu audio-vizuelnih sredstava u nastavi stranog jezika struke. Osim toga, ohrabrujuć je zaključak da i kod predavača i kod studenata postoji velika zainteresovanost za ovaj vid nastave. Uz to, kako predavači tako i studenti ističu da se korišćenjem audio-vizelnih sredstava u nastavi stranog jezika struke nastava unapređuje, poboljšava se zainteresovanost, a samim tim i motivacija studenata za učenje stranog jezika. Upotrebom audio-vizuelnih sredstava takođe se razvijaju i poboljšavaju lingvističke, sociokulturne, interkulturne i pragmatske kompetencije studenata u okviru nastave stranog jezika struke. Posebno se ističe činjenica da svi predavači (100\%) smatraju da se upotrebom audio-vizuelnih sredstava najviše razvijaju veštine razumevanja govora, lingvistička i sociokulturna kompetencija. Pored toga, najveći broj studenata $(87,5 \%)$ u potpunosti se slaže sa tvrdnjom da im se dopada nastava koja se izvodi na ovaj način uz primenu audio-vizuelnih sredstava. Stoga se može zaključiti da su obe postavljene hipoteze potvrđene datim istraživanjem.

Kao najveći nedostatak u primeni audio-vizuelnih sredstava u nastavi stranog jezika struke mogle bi se smatrati poteškoće određenog broja studenata da prate filmove na stranom jeziku iz razloga što je njihovo znanje stranog jezika na nižem nivou od očekivanog ili ukoliko na fakultetu ne postoji odgovarajuća tehnička oprema koja bi omogućila korišćenje ovih sredstava u nastavi.

Kao ograničenje ovog istraživanja mogao bi se navesti relativno mali broj ispitanika, kako predavača tako i studenata koji su se odazvali datom upitniku. Međutim, ovo preliminarno istraživanje svakako bi moglo poslužiti kao izvesna polazna osnova za buduća obimnija istraživanja o upotrebi audio-vizuelnih sredstava u nastavi, kao i o uticaju koji audio-vizuelni materijali mogu imati na krajnja postignuća studenata u okviru nastave stranog jezika struke, a u cilju što boljeg ovladavanja stranim jezikom. 


\section{Literatura}

Al-Khayyat, A. S. J. (2016). The Impact of Audio-Visual Aids ( AVA ) and Computerize Materials ( CM ) on University ESP Students' Progress in English Language. International Journal of Education and Research, 4(1), 273-282.

Ashaver, D., \& Igyuve, S. M. (2013). The Use of Audio-Visual Materials in the Teaching and Learning Processes in Colleges of Education in Benue State-Nigeria. IOSR Journal of Research \& Method in Education (IOSRJRME), 1(6), 44-55. https://doi.org/10.9790/7388-0164455

Allan, M. (1985). Teaching English with Video. London: Longman.

Biedma Torrecillas, A. \& Torres Sánchez, M. A. (1994). El estímulo cinematográfico: desarrollo de destrezas comunicativas y valor cultural. In J. Sánchez Lobato \& I. Santos Gargallo (Eds.), Problemas y métodos en la enseñanza del español como lengua extranjera. Actas del IV Congreso Internacional de ASELE (pp. 537-552). Universidad Complutense de Madrid.

Brady, S. (1992). El uso del video en la enseñanza de los idiomas. In R. Losada Durán (Ed.), Actas del VIII Congreso Nacional de Lingüística Aplicada, Vigo (pp. 169172). Asociación Española de Lingüística Aplicada.

Brandimonte, G. (2003). El soporte audiovisual en la clase de E/LE: el cine y la televisión. In H. Perdiguero \& A. Álvarez (Eds.), Medios de comunicación y enseñanza del español como lengua extranjera. Actas del XIV Congreso Internacional de ASELE (pp. 870-881). Universidad de Burgos.

Canning-Wilson, C. (2000). Practical Aspects of Using Video in the Foreign Language Classroom. The Internet TESL Journal, vol. VI, 11. Retrived May 11, 2014 from the World Wide Web http://iteslj.org/Articles/Canning-Video.2001 html.

Coppen, H. (1978). Utilización didáctica de los medios audiovisuales. (traducción: P. Hidalgo Andreau). Madrid: Anaya.

Ferrés Prats, J. (1992). Vídeo y educación. Barcelona: Ediciones Paidós.

Gollin-Kies, S., Hall, D. R., \& Moore, S. H. (2015). Language for Specific Purposes. Basingstoke: Palgrave Macmillan.

Hornjak, S. (2017). Film u nastavi španskog jezika. Beograd: Zadužbina Andrejević.

Radosavlevikj, N., \& Hajrullai, H. (2019). Using Video Presentations in ESP Classes (A Study Conducted at the Language Centre-Skopje, SEEU), SEEU Review, 14(1), 178-195. doi: https://doi.org/10.2478/seeur-2019-0010 
Milosevic, D. (2017). Using video materials in English for technical sciences: a case study. In C. Sarré \& S. Whyte (Eds.), New developments in ESP teaching and learning research (pp. 15-30). Research-publishing.net. https://doi.org/10.14705/rpnet.2017.cssw2017.743

Molina i Simó, L. (1990). El vídeo: uso pedagógico y profesional en la escuela (traducción: M. Zaragoza). Barcelona: Editorial Alta Fulla.

Mutar, S. S. (2009). The Effect of Using Technical Audio Visual-Aids on Learning Technical English Language at Technical Institutes. Misan Journal for Academic Studies, 8(15), 1-7.

Sarceda Gorgoso, M. C. \& Raposo Rivas, M. (2009). Integrando el cine en educación: Razones normativas y curriculares para su uso en Primaria. In M. Raposo Rivas (Ed.), El cine en educación: Realidades y propuestas para su utilización en el aula (pp. 39-48). A Coruña: Tórculo Artes Gráficas.

Woottipong, K. (2014). Effect of Using Video Materials in the Teaching of Listening Skills for University Students. International Journal of Linguistics, 6(4), 200-212. https://doi.org/10.5296/ijl.v6i4.5870

\section{Summary}

\section{AUDIO-VISUAL RESOURCES IN TEACHING LANGUAGES FOR SPECIFIC PURPOSES}

In order to modernise the teaching of languages for specific purposes (LSP) and increase the motivation of students, a constant effort is made to improve both teaching materials and introduce various tools. In this regard, the paper discusses the advantages of using audio-visual resources for didactic purposes. For this research, a survey was conducted among LSP practitioners at the University of Belgrade, as well as among second-year undergraduate students who attended LSP classes at the Faculty of Agriculture, University of Belgrade. The subject of the research is to examine the attitude of LSP practitioners and students of languages for specific purposes towards the application of these resources in LSP classes. The research aims to consider the (non)existence of preconditions for the application of audio-visual resources in the teaching of languages for specific purposes. These results indicate numerous advantages of the application of audio-visual resources and the need for their application, as well as for further research in this area. LSP practitioners, as well as students, believe that the use of audiovisual resources in teaching is beneficial because, above all, it makes teaching more interesting and the material clearer, and thus motivates students to learn a foreign language for specific purposes.

Keywords: languages for specific purposes, audio-visual resources, language skills and competences, research, attitudes of lecturers/students 